\title{
DEVELOPMENT OF MAINLINE ELECTRIC LOCOMOTIVE ENGINEERING IN UKRAINE (ON THE EXAMPLE OF DIVERSIFICATION OF PRODUCTION ACTIVITY OF OJSC «LUHANSKTEPLOVOZ»)
}

Target setting. During 1988-2000 the production volume of locomotives of the holding company «Luganskteplovoz» decreased from 1339 to 3 sections, and during 2002 no locomotive was manufactured [30, p. 241]. One of the measures to stabilize the economic situation of the company was the development of industrial production of new type rolling stock in accordance with the current needs of transport. However, given the political situation, as well as the traditional focus on the development of rolling stock projects with internal combustion engines, $\mathrm{HC}$ «Luhanskteplovoz» in the absence of sustainable public investment lost its design potential until privatization. As, according to official data, the wear of the fleet of electric locomotives of JSC «Ukrzaliznytsia» reaches more than $90 \%$, the possibility of importing traction rolling stock with the prospect of further localization of production is being actively considered. Hence, we believe that the analysis of production activities of railway engineering enterprises of Ukraine is relevant given the need to determine the conceptual ways of harmonizing their design and technological basis with modern needs in the renewal of the fleet of transport operators.

Actual scientific researches and issues analysis. Unfortunately, for a long time, the circumstances of the development of the main electric locomotive engineering in Ukraine have not found their comprehensive coverage in domestic historiography, the only exceptions are isolated data in the monographs of $\mathrm{O}$. Buyanov [10], V. Rakov [26; 27], and Yu. Tsygankov-Serebryakov [30].

The article aims to cover the historical circumstances of the development of the Ukrainian main electric locomotive industry on the basis of a comprehensive analysis of sources and scientific literature on the example of diversification of production activities of the State Holding Company «Luhanskteplovoz».

The statement of basic materials. During 19571967, with the beginning of the development of new products, Luhansk locomotive plant gained experience in manufacturing the crew parts of electric locomotives series VL8 and VL10 [27, p. 21; 33], and in 1966 at the enterprise the monomotor cart of the experimental electric locomotive VL40 was created [10, p. 166-167]. Since in the mid-1960s the Tbilisi electric locomotive plant established the supply of mechanical parts of elec- tric locomotives from the Novocherkassk plant in September 1967, the electric locomotive shop of the Luhansk plant was reorganized into a machine-assembling one $[27$, p. 33]. For a long time, the fleet of passenger electric locomotives of the USSR was replenished by supplies from Czechoslovakia. As rail passenger traffic reached a critical level in the late 1970s, there was a need to increase the number of cars and, consequently, to increase the weight of trains. The basis of the passenger fleet of the USSR were six-axle electric locomotives with a capacity of 4200-5100 kW, and traction forces up to 17,4 tf, which was not enough to drive 30car trains. In 1982, the Škoda plant created two-section eight-axle passenger electric locomotives with a capacity of $6160-7200 \mathrm{~kW}$ and a thrust of $25,29-29,1 \mathrm{tf}$, designed to drive heavy trains [26, p. 35; 59]. The next stage involved the creation of single-section eight-axle locomotives with asynchronous traction motors with a capacity of $7200-8000 \mathrm{~kW} \mathrm{[26,} \mathrm{p.} \mathrm{211-212].} \mathrm{How-}$ ever, since 1989, due to the lack of convertible currency, the volume of imports of equipment began to decline significantly, conceptual designs of Škoda locomotives gradually lost their relevance, and in the USSR there was a need to expand the range of electric locomotives.

In the late 1980s, the economic activity of the Production Association «Luhanskteplovoz» was costly, there were significant problems with logistics, as well as reducing the cost of production. Since 1988, the Association switched to self-financing and started measures for the introduction of new production sites [30, p. 220]. However, by mid-1989, the accumulated imbalances in development plans were complicated by the inertia of the spending mechanism and the lack of a clear crisis recovery strategy. Wage growth outpaced its productivity by $21,1 \%$. Since August 1988, the Association's expenses exceeded its profits, and its debt to suppliers, which was covered by loans. During 1988-1989 alone, wages were paid 40 times through loans. For 9 months of 1989 , the increase in credit investments was $8,6 \%$, and the volume of marketable products decreased by $0,6 \%[30$, p. 229-230]. Against the background of declining demand for mainline locomotives, one of the ways to stabilize the economic situation was to expand the range of production. In the early 1990s, there was an acute shortage of passenger electric locomotives on the Soviet railways, and the existing locomotives produced 
by the Škoda plant were used only on the busiest lines. Execution of the order for the creation of new electric locomotives was entrusted to the NGO «Novocherkassk electric locomotive plant», NGO «Elektrovozobudivnyk» (Tbilisi) and PA «Luhanskteplovoz», designers of which in order to speed up the organization of production decided to create universal freight-passenger electric locomotives of the transitional type, and later to move to the development of passenger locomotives of advanced design.

At the beginning of 1991, Deputy Minister of Railways of the USSR B. Nikiforov within the framework of the agreement concluded with PA «Luhanskteplovoz», signed an application for the creation of a singlesection eight-axle freight passenger electric locomotive with a capacity of $6400 \mathrm{~kW}$ based on the crew of the experimental locomotive TE136 with microprocessor control and diagnostic system. Conventional serial designation of the electric locomotive of alternating current was EL-1, direct current - EL-2. The annual output was to be 100 locomotives of each series. In December 1991 the preliminary sketch design of the locomotive was defended, and in February 1992 the design development of technical documentation began. According to the agreement, the completion of the development of technical documentation was planned for January 1993, the production of the experimental electric locomotive EL-2 - I quarter of 1994, EL1 - IV quarter of 1994. Due to the fundamental differences in electric locomotive technologies at the enterprise, the creation of a new experimental production base was envisaged [15].

After the proclamation of Ukraine's independence on December 14, 1991, the Cabinet of Ministers of Ukraine adopted Resolution № 356 «On the Establishment of the State Administration of Railway Transport of Ukraine» - «Ukrzaliznytsia» [19, p. 8]. At that time, Ukraine was considering the transition of the entire railway network to electric rolling stock. At that time, out of $22700 \mathrm{~km}$ of highways, only $8400 \mathrm{~km}$ were electrified. «Ukrzaliznytsia» developed a program to electrify $1667 \mathrm{~km}$ of tracks as a matter of priority. The implementation of the program was to increase the transportation of goods by electric traction on average from 64,5 to $75 \%$, and the transfer of $1 \%$ of freight turnover to electric traction annually reduced the cost of railways by 2700000000 rubles in 1984 prices [19, p. 21]. However, from the existing fleet of locomotives of «Ukrzaliznytsia» of 1300 units by 2001, 57\% of freight and $73 \%$ of passenger electric locomotives were to be operated above the norm [31, p. 3].

In the absence of a convertible currency for the purchase of sufficient equipment abroad, the management of «Ukrzaliznytsia» decided to combine imports with the organization of rolling stock production at domestic industry plants. At the beginning of June 1992, the «Ukrzaliznytsia» Main Department presented projects of a freight and passenger electric locomotive PA «Luhanskteplovoz» with a capacity of $6400 \mathrm{~kW}$, as well as a two-section eight-axle freight and passenger electric locomotive with a capacity of $6250 \mathrm{~kW}$, developments of the SPA «Dnipropetrovsk electric locomotive plant», which specializes in small-scale production of industrial electric vehicles [32, p. 229]. In July 1992, the «Program for the Development of Railway Transport of Ukraine», was approved, calculated till 1998. During this time, PA «Luhanskteplovoz» had to master the production of 7 new types of rail machines, including two modifications of electric passenger locomotives [30, p. 235].

At the end of 1992, an eight-axle two-axle two-section DC electric locomotive E13 with a capacity of $6000 \mathrm{~kW}$, a thrust of $32,8 \mathrm{tf}$, and a speed of $100 \mathrm{~km} / \mathrm{h}$ was introduced on the Russian market developed by SPA «Elektrobudivnyk» (Tbilisi), as well as a singlesection six-axle freight passenger electric locomotive of alternating current VL65 with a capacity of $5010 \mathrm{~kW}$, a thrust of 24,98 tf and a speed of $120 \mathrm{~km} / \mathrm{h}$ developed by SPA «NEVZ» (Novocherkassk) [7, p. 117; 230]. Alongside, the designers of the Kolomensk locomotive plant together with SPA «NEVZ» developed a project of a high-speed eight-axle single-section AC passenger electric locomotive with a capacity of $8180 \mathrm{~kW}$, a thrust of $24 \mathrm{tf}$, and a speed of $250 \mathrm{~km} / \mathrm{h}$ on the basis of the experimental locomotive TEP80 [7, p. 237]. According to official data, by $2000,50 \%$ of Russia's electric locomotive fleet (more than 12800 locomotives) was to reach the age limit and be written off, while in 1993-1995 alone, the annual cost of purchasing imported electric locomotives was to be USD 78500000 [9, p. 484; 487]. After completion of tests of experimental locomotives, the management of the Ministry of Railways of the Russian Federation decided to limit imports with the organization of production of DC electric locomotives in the framework of the conversion of a number of enterprises of the military-industrial complex [9, p. 486]. Thus, by the mid-1990s in Russia, there were preconditions for the formation of the domestic market of producers of mainline electric locomotives, which finally crossed the urgency of the prospects of importing not only products manufactured by PA «Luhanskteplovoz» but also SPA «Elektrobudivnyk».

On October 22, 1992, by order of the Ministry of Mechanical Engineering, Military-Industrial Complex and Conversion of Ukraine, the State Enterprise «Ukrainian Research, Design and Technological Institute of Electric Locomotive Engineering» was established within the SPA «Dnipropetrovsk electric locomotive plant», which was entrusted with the functions of the main scientific organization for electric locomotive engineering [32, p. 219], and already on June 26, 1993, by the Resolution of the Cabinet of Ministers of Ukraine № 480 «On development and production in 1993-2000 years of main freight and passenger electric locomotives» the Association was designated «the main manufacturer of mainline freight and passenger electric locomotives» [24]. According to the plan, by 2000230 freight electric locomotives of direct current, 85 passenger electric locomotives of direct current, 80 freight 
electric locomotives of alternating current, and 35 passenger electric locomotives of alternating current were to be made. Deep modernization of SPA «DEVZ» and enterprises included in the corporation «Ukrelectrovoz» created to coordinate research and development, was envisaged. The corporation also included PA «Luhanskteplovoz», which supplied individual electric locomotive components $[31$, p. 4$]$. The total amount of financing of works and capital investments for the creation of production facilities of SPA «DEVZ» amounted to 122899100000 rubles in prices of 1993 [24].

Instead, on June 4, 1994, the Resolution of the Cabinet of Ministers of Ukraine № 364 «On organization of production of cars of diesel and electric trains» entrusted the Ministry of Mechanical Engineering, Military-Industrial Complex and Conversion with the functions of coordinating the development of electric train cars, the creation of production facilities and the organization of their production, and the PA «LuhanskteploVoz» - with the functions of the manufacturer of final products. According to the plan, by 1998 inclusive, 400 cars of DC electric trains and 280 cars of AC electric trains were to be manufactured. The total amount of funding for research and development, as well as capital investments to upgrade the production facilities of the Association amounted to 1482400000000 rubles in prices of 1994 [25] (only 14596297755 rubles in prices of $1993-11,8 \%$ compared to the financing of the electric locomotive industry). Thus, due to the changing political situation, PA «Luhanskteplovoz» lost its order to develop electric locomotives, while its diversification was directed in a less investment-attractive direction of production of railcar rolling stock. In addition, as a result of the gradual collapse of the single economic complex of the Association into a number of independent enterprises, which led to the loss of control, unjustified diversification, and additional production costs, the preconditions for deepening its crisis were laid [30, p. 265 - 266]. On May 19, 1995, by the Decree of the President of Ukraine, the State Holding Company «Luhanskteplovoz» was established on the basis of the Association [30, p. 236]. In 1996, investment in the renewal of the fleet of electric locomotives was identified as the first priority in the sequence of calculations of «Ukrzaliznytsia», while locomotives and suburban rolling stock - the last [19, p. 66]. In the summer of 1996, «Ukrzaliznytsia» purchased the last batch of 10 passenger electric locomotives manufactured by the Škoda plant, SPA «DEVZ» presented an experimental main freight electric locomotive DE1 with a collector drive with a capacity of $6260 \mathrm{~kW}$, a thrust of 43,542 tf and a speed of $100 \mathrm{~km} / \mathrm{h}$ [17, p. 13; 19, p. $94-95]$, and $\mathrm{HC}$ «Luhanskteplovoz» - the first diesel train with asynchronous drive DEL-01 [30, p. 242].

The next stage involved the development of electric locomotives with an asynchronous drive. Alstom, HITACHI and Siemens took part in the tender for the supply of equipment for the future locomotive, developed by SPA «DEVZ» [31, p. 5]. An alternative project was initiated by $\mathrm{HC}$ «Luhanskteplovoz», which in cooperation with the German company Adtranz planned to master the industrial production of a single-section four-axle AC freight electric locomotive with an asynchronous traction drive BR-145 with a capacity of $4140 \mathrm{~kW}$, a speed of $140 \mathrm{~km} / \mathrm{h}$, and a thrust of $30,59 \mathrm{tf}$ for the CIS market [30, p. 267; 277]. Developed during 1994 - 1997, the BR-145 electric locomotives became the basis for the Adtranz Octeon modular platform, which provided for the possibility of making design changes at the request of the customer. However, in 1998 an agreement was signed between SPA «DEVZ» and the German group company Siemens for the joint development and production of a four-axle single-section freight electric passenger locomotive DS3 with a capacity of $4800 \mathrm{~kW}$, a thrust of $16,4 \mathrm{tf}$ and a speed of $160 \mathrm{~km} / \mathrm{h}$ [31, p. 5]. During 1999-2001 HC «Luhanskteplovoz» presented prototypes of diesel trains of constant formation DPL-1 and DPL-2, as well as electric trains of direct current EPL2T-001 and alternating current - EPL9T. In 2001, the share of electric trains in the company's product range was $49,3 \%$, diesel trains $15,5 \%$, while diesel locomotive - only $14,2 \%$. During the year, the growth rate of production amounted to $151,3 \%$, and the volume of manufactured products UAH 89500000 [30, p. 300 - 301].

Since during 1990-2004 the share of freight transportation by rail in Ukraine increased from 15,5 to $27 \%$ [14, p. 302], a SPC «Elektrovozobuduvannia» in the absence of sustainable funding did not master the production of a number of types of locomotives, on December 1, 2004, an agreement was signed between «Ukrzaliznytsia», JSC «Roslokomotiv» (CJSC «Transmashholding») and $\mathrm{HC}$ «Luhanskteplovoz» concerning the organization of production of 50 two-section freight electric locomotives with collector traction motors of alternating current till 2011. The contract sum, which provided for the development of design documentation, production of a research locomotive at the Novocherkassk electric locomotive plant and supply of equipment amounted to EUR 100000000 [30, p. 336]. Industrial production was carried out at the facilities of $\mathrm{HC}$ «Luhanskteplovoz» and as the level of localization increased, the share of Russian equipment was to gradually decrease to $35-40 \%$ of the initial volume. In December 2005, an experimental electric locomotive was built on the basis of the Russian prototype 2ES5K with a capacity of $6560 \mathrm{~kW}$, a thrust of $47,3 \mathrm{tf}$, and a speed of $110 \mathrm{~km} / \mathrm{h}$, which received the serial designation $2 \mathrm{EL} 5$ [30, p. 349]. On March 23, 2007, CJSC «Transmashholding» acquired a state-owned stake with $76 \%$ of shares in HC «Luhanskteplovoz» for USD 58000000 [21]. At the end of 2007, a set of tests to confirm the operational parameters of the 2EL5 electric locomotive was completed [8]. In 2008, the company manufactured 9 2EL5 electric locomotives and 56 electric train cars. According to the results of 11 months of work in 2008, the growth rate of production was almost $200 \%$, and the volume of manufactured products reached a record for 
17 years - UAH 1284000 000. Labor productivity increased by $120 \%$ and the average wage by $60 \%$ [21].

In October 2008, the Ministry of Transport of Ukraine approved the "Comprehensive program for the renewal of railway rolling stock of Ukraine for $2008-2020 »$, which identified the need to replenish the locomotive fleet with passenger electric locomotives in the amount of 282 units and dual-system electric locomotives - 110 units [28]. As, according to «Ukrzaliznytsia» CEO M. Kostiuk SPC «Electrovozobuduvannia» invested «in the development of obsolete technology» [12], the state monopolist lost interest in the company's products, including the passenger electric locomotive DS3 and the two-system electric locomotive DS-4 created on its basis. Due to problems with operation and the appearance on the market of a more advanced Russian electric locomotive $2 \mathrm{ES} 4 \mathrm{~K}$, the cost of which, taking into account customs clearance, was lower, the ordering of electric locomotives of the DE1 series was also stopped [17, p. 14]. In March 2009 HC «Luhanskteplovoz», with the support of LLC «Novocherkassk electric locomotive plant», started production of two-section 2EL4 DC electric locomotives with a capacity of $6400 \mathrm{~kW}$, a thrust of $44 \mathrm{tf}$ and a design speed of $120 \mathrm{~km} / \mathrm{h}$, created on the basis of the russian electric locomotive 2ES4K [22]. The company's management expressed readiness to start developing a two-system electric locomotive on the basis of own developments under the condition of preliminary financing. According to $\mathrm{CEO} \mathrm{V}$. Bikadorov, the cost of the prototype reached EUR 3000000 [12]. However, the global economic crisis of 2008-2009 slowed down the development of electric locomotive construction in the product range of $\mathrm{HC}$ «Luhanskteplovoz», and the production of electric trains was virtually stopped. The total production of the company decreased by 66,5\% to UAH 429661000 [20; 33]. Despite planned by financial plans of «Ukrzaliznytsia» orders for 18 electric locomotives of both modifications, in fact during 2009-2011 in the absence of targeted funding $\mathrm{HC}$ «Luhanskteplovoz» produced only 10 units $[3 ; 18 ; 33]$.

In the spring of 2011, the management of «Ukrzaliznytsia» announced the final decision to abandon the purchase of products of SPC «Elektrovozobuduvannia» and to hold a tender between the companies PJSC «Luhanskteplovoz» and JSC «Elektrovozobudivnyk» (Georgia) [16]. On July 20, 2011, a memorandum was signed between «Ukrzaliznytsia», Luhansk Regional State Administration, CJSC «Transmashholding» and PJSC «Luhanskteplovoz» for the production during 2012-2016 of 262 electric locomotives of series 2EL4 and 30 electric locomotives of series 2EL5 [13]. According to experts, the estimated cost of the transaction was USD 1700000 000. Since at that time the level of localization of production of the 2EL5 series electric locomotive reached $70 \%$, while $2 \mathrm{EL} 4$ - only $10 \%$, there was a requirement to increase it to $80 \%$. Instead, the company's management stressed that the development of serial production of electric locomotives 2EL4 with a level of localization of more than $70 \%$ would take at least 2 years [13]. According to the results of 2011, the total volume of manufactured products of the company increased by $62 \%$ from UAH 956000000 to UAH 1550000000 [33]. In the spring of 2013, PJSC «Luhanskteplovoz» received a state order for the manufacture of 300 electric locomotives with a total value of UAH 12000000000 [5], and in the fall of 2013, a contract was concluded for the supply of 70 electric locomotives of the 2EL5 series to SE «Odessa Railway» by 2017 [4]. In November 2013, 2 2EL4 electric locomotives were manufactured as part of the order [23]. However, given the location of PJSC «Luhanskteplovoz» $n$ the occupied territory and the orientation of production of electric locomotives for the needs of the Ukrainian market, the promising direction of diversification of the company was curtailed.

Conclusion. Thus, for a long time Luhansk diesel locomotive plant, having a strong research and production potential, developed and created unique projects of new generation railway equipment, which were exported to many countries. In the late $1980 \mathrm{~s}$, in the absence of a convertible currency in the country for the import of electric locomotives from Czechoslovakia, against the background of a gradual decline in demand for mainline locomotives and exacerbation of the economic crisis PA «Luhanskteplovoz» was given the opportunity to expand the range of production under the state order for the development of passenger electric locomotives of its own design. However, after 1991, due to the strategy of the Ministry of Railways of the Russian Federation to support the domestic market of mechanical engineering and lobbying of the renewed $\mathrm{Ca}-$ binet of Ministers of Ukraine concerning on directing the main investments to create a state monopoly corporation on the basis of low-power SPA «Dnipropetrovsk electric locomotive plant», diversification of production activities of $\mathrm{HC}$ «Luhanskteplovoz» focused on the less promising direction of production of railcar rolling stock. We believe that the fundamental aspect of the establishment of «Ukrteplovoz» corporation was to ensure its activity not on the basis of opposition, but of close interaction of research and production potentials of domestic locomotive enterprises, such as the experience of cooperation between Luhansk and Tbilisi plants in the production of main electric locomotives in the 1960s. However, due to the low quality of products, caused by the lack of sound experience in the development of crew parts of the mainline equipment, the order of electric locomotives of SPC «Elektrovozobuduvannia» (SPA «DEVZ») was stopped. The further development of industrial production at the facilities of $\mathrm{HC}$ «Luhanskteplovoz» of new generation freight electric locomotives, created on the basis of design and technological products of LLC «Novocherkassk electric locomotive plant», allowed in a short time to significantly increase the growth of manufactured products and expand promising areas of cooperation with «Ukrzaliznytsia». 
Prospects for further elaboration of the issue. The elaboration of issues of further development of domestic machine-building enterprises and their influence on the technological security of the rolling stock of JSC «Ukrzaliznytsia» should be carried out taking into account the achievements of Ukrainian science on the issues of structural adjustment of the national economy [29]. The developments on comparative analysis of the profile of the Ukrainian manager should also be used [2], which will require systematic research on the methodology of national business cultures [1].

\section{Literature}

1. Chebotarov Ie. National business cultures: research methodology, content and role in provision of international entrepreneurship. Economic Herald of the Donbas. 2019. № 4 (58). P. 30-33. Doi: 10.12958/1817-37722019-4(58)-30-33. 2. Glinkowska-Krauze B., Chebotarov V., Chebotarov Ie. Comparative Studies of National Business Cultures in the Countries of Central and Eastern Europe: the Basics for Improving International Entrepreneurship in Poland and Ukraine. Comparative Economic Research. 2020. Vol. 23. № 1. P. 7-18. Doi: http://dx.doi.org/10.18778/1508-2008.23.01. 3. «Лугансктепловоз» выполняет заказы РЖД. Украинская техническая газета. 2011. 11 октября (№ 39). С. 3. 4. «Лугансктепловоз» поможет одесситам. Наша газета (Луганск). 2013. 11 сентября (№ 131). С. 2. 5. «Лугансктепловоз» поставит «Укрзалізниці» 300 электровозов. Наша газета (Луганск). 2013. 21 мая (№ 70). С. 6. 6. «Укрзализныця» закупит 16 локомотивов. Экономические известия (Киев). 2010. 18 октября (№ 178). C. 4. 7. Абрамов Е. Р. (Ред.) Электроподвижной состав Отечественных железных дорог. Санкт Петербург, 2015. 561 с. 8. Борисенко Г. Переменная и постоянная «Лугансктепловоза». Украинская техническая газета. 2010. 25 мая (№ 21). С. 1, 8. 9. Бочаров В. И. 60 лет в строю. Ростов н/Д: Изд-во «Приазовский край», 1996. 640 с. 10. Буянов А. Ф. Творцы новой техники. Луганск: Книжковий світ, 2005. 288 с. 11. Герасимова Е. Французский вектор «Лугансктепловоза». Украинская техническая газета. 2010. 24 августа (№ 33-34). С. 5. 12. Гребеник Е. «Укрзалізниця» ищет электровоз. Экономические известия (Киев). 2009. 16 ноября (№ 206). С. 4. 13. Гребеник Е. «Укрзалізниця» требует отечественного. Экономические известия (Киев). 2011. 29 сентября (№ 168). С. 1. 14. Данилишин Б. М. (Ред.) Машинобудування в Україні: тенденції, проблеми, перспективи. Ніжин: «Аспект-Поліграф», 2007. 308 с. 15. Ладыженский $\Gamma$. Создается украинский электровоз. Октябрьский гудок (Луганск). 1992. 4 февраля (№ 7). С. 3. 16. Леднев А. «Укрзализныця» отцепила «Электровозостроение». Коммерсантъ Украина (Киев). 2011. 16 мая (№ 74). С. 5. 17. Ліхушин Є. В. Електровоз ДЕ1: створення і експлуатація. Локомотив інформ. Харків: Рухомий склад, 2018. № 11. С. 12-16. 18. Луганским тепловозам - зеленый свет. Украинская техническая газета. 2010. 13 июля (№ 27). С. 2. 19. Москаленко П., Мукмінова Т. Укрзалізниця. Поступ часу. 1991 - 1996. Матеріали до історії залізничного транспорту України. Київ: Транспорт України, 1996. 336 с. 20. Особова Е. «Лугансктепловоз» между сокращением каждого четвертого и полной остановкой. Украинская техническая газета. 2009. 28 апреля (№ 18). С. 5. 21. Павлюк І. Аукціон небаченої безкорисливості. Украинская техническая газета. 2010. 22 июня (№ 25-26). С. 6. 22. Первый Луганский. Украинская техническая газета. 2009. 2 апреля (№ 14). С. 3. 23. ПАО «Лугансктепловоз» наращивает темпы. Наша газета (Луганск). 2013. 17 декабря (№ 186). С. 2. 24. Про розробку і виробництво у $1993-2000$ роках магістральних вантажних і пасажирських електровозів: Постанова Кабінету Міністрів України від 26 червня 1993 p. № 480. URL: https://zakon.rada.gov.ua/laws/ show/480-93-\%D0\%BF. 25. Про організацію виробництва вагонів дизель- та електропоїздів: Постанова Кабінету Міністрів України від 4 червня 1994 р. № 364. URL: https://zakon.rada.gov.ua/laws/show/364-94-\%D0\% BF\#Text. 26. Раков В. А. Локомотивы и моторвагонный подвижной состав железных дорог Советского Союза (1976-1985 гг.). Москва: Транспорт, 1990. 238 с. 27. Раков В. А. Локомотивы отечественных железных дорог (1956-1975 гг.). Москва: Транспорт, 1999. 443 с. 28. Спектор В. В контексте времени. Украинская техническая газета. 2009. 5 февраля (№ 6). С. 10. 29. Структурні реформи економіки: світовий досвід, інститути, стратегії для України: монографія / O. I. Амоша, С. С. Аптекар, М. Г. Білопольський, С. І. Юрій та ін.; ІЕП НАН України; ТНЕУ МОНМС України. Тернопіль: Економічна думка ТНЕУ, 2011. 848 с. 30. Цыганков-Серебряков Ю. В. Люди. Годы. Факты. ОАО «ХК» Лугансктепловоз». Луганск, 2006. 479 с. 31 . Чумак В. В. Браташ В. А. Перспективы развития электровозостроения в Украине. Транспорт. Дніпропетровськ: ДДТУЗТ, 2002. Вип. 11. С. 3-6. 32. Шатовский А., Волнянский Г. Рожденный трижды: очерки истории научно-производственного объединения "ДЭВЗ". Люди. События. Годы. Днепропетровск, 1998. 263 с. 33. Юрова С., Спектор В. Сергей Михеев: «У нас славное прошлое и хорошие перспективы». Украинская техническая газета. 2011. 31 мая (№ 20). С. 5.

\section{References}

1. Chebotarov, Ie. (2019). National business cultures: research methodology, content and role in provision of international entrepreneurship. Economic Herald of the Donbas, 4 (58), pp. 30-33. Doi: 10.12958/1817-3772-20194(58)-30-33.

2. Glinkowska-Krauze, B., Chebotarov, V. \& Chebotarov, Ie. (2020). Comparative Studies of National Business Cultures in the Countries of Central and Eastern Europe: the Basics for Improving International Entrepreneurship in Poland and Ukraine. Comparative Economic Research, Vol. 23, No. 1, pp.7-18. Doi: http: //dx.doi.org/10.18778/1508-2008.23.01.

3. «Luganskteplovoz» pomozhet odessitam [«Luganskteplovoz» will help Odessa residents]. (2013). Nasha gazeta, September 11 (№ 131), p. 2. [in Russian].

4. «Luganskteplovoz» postavit «Ukrzalíznitsí» 300 elektrovozov [«Luganskteplovoz» will supply to «Ukrzalíznitsya» 300 electric locomotives]. (2013). Nasha gazeta, May 21 (№ 70), p. 6 [in Russian].

5. «Luganskteplovoz» vypolnyayet zakazy RZHD [«Luganskteplovoz» fulfills orders of Russian Railways]. 
(2011). Ukrainskaya tekhnicheskaya gazeta, October 11 (№ 39), p. 3 [in Russian].

6. «Ukrzalíznitsya» zakupit 16 lokomotivov [«Ukrzaliznytsia» will purchase 16 locomotives]. (2010). Ekonomicheskiye izvestiya, October 18 (№ 178), p. 4 [in Russian].

7. Abramov, E. P. (Ed.) (2015). Elektropodvizhnoy sostav Otechestvennykh zheleznykh dorog [Electric rolling stock of domestic railways]. Saint Petersburg. 561 p. [in Russian].

8. Borisenko, G. (2010). Peremennaya i postoyannaya «Luganskteplovoza» [Variable and constant of "Luganskteplovoz"]. Ukrainskaya tekhnicheskaya gazeta. May 25 (№ 21), p. 1, 8 [in Russian].

9. Bocharov, V. I. (1996). 60 let v stroyu [60 years in the ranks]. Rostov-on-Don, Izd-vo «Priazovskiy kray». 640 p. [in Russian].

10. Buyanov, A. F. (2005). Tvortsy novoy tekhnyky [Creators of new technology]. Lugansk, Knyzhkovyy svit. 288 p. [in Russian].

11. Gerasimova, Ye. (2010). Frantsuzskiy vektor «Luganskteplovoza» [French vector of «Luganskteplovoz»]. Ukrainskaya tekhnicheskaya gazeta, August 24 (№ 33-34), p. 5 [in Russian].

12. Hrebenik, Ye. (2009). «Ukrzaliznytsya» ishchet elektrovoz [«Ukrzaliznytsia» is looking for an electric locomotive]. Ekonomicheskiye izvestiya, November 16 (№ 206), p. 4 [in Russian].

13. Hrebenik, Ye. (2011). «Ukrzaliznytsya» trebuyet otechestvennogo [«Ukrzaliznytsia» requires domestic]. Ekonomicheskiye izvestiya, September 29 (№ 168), p. 1. [in Russian].

14. Danylyshyn, B. M. (Ed.). (2007). Mashynobuduvannia v Ukraini: tendentsii, problemy, perspektyvy [Mechanical engineering in Ukraine: tendencies, problems, prospects]. Nizhyn, «Aspekt-Polihraf», 308 p. [in Ukrainian].

15. Ladyzhensky, G. (1992). Sozdayetsya ukrainskiy elektrovoz [Ukrainian electric locomotive is being created]. Oktyabrskiy gudok, February 4 (№ 7), p. 3 [in Russian].

16. Lednev, A. (2011). «Ukrzaliznytsya» ottsepila «Elektrovozostroyeniye». ["Ukrzaliznytsia" unhooked "Elektrovozostroyeniye"]. Kommersant Ukraina, May 16 (№ 74), p. 5 [in Russian].

17. Likhushyn, Y. V. (2018). Elektrovoz DE1: stvorennia i ekspluatatsiia [Electric locomotive DE1: creation and operation]. Locomotive inform, 11, p. 12-16. Kharkiv, Rukhomyi sklad [in Ukrainian].

18. Luganskim teplovozam - zelenyy svet [Lugansk diesel locomotives - green light] (2010). Ukrainskaya tekhnicheskaya gazeta, July 13 (№ 27), p. 2 [in Russian].

19. Moskalenko, P. \& Mukminova, T. (1996). Ukrzaliznytsia. Postup chasu. 1991 - 1996. Materialy do istorii zaliznychnoho transportu Ukrainy [Ukrzaliznytsia. The progress of time. 1991 - 1996. Materials on the history of railway transport in Ukraine]. Kyiv, Transport Ukrayiny, 336 p. [in Ukrainian].

20. Osobova Ye. (2009). «Luganskteplovoz» mezhdu sokrashcheniyem kazhdogo chetvertogo i polnoy ostanovkoy [«Luganskteplovoz» between the reduction of every fourth and a complete stop]. Ukrainskaya tekhnicheskaya gazeta, April 28 (№ 18), p. 5 [in Russian].
21. Pavliuk, I. (2010). Auktsion nebachenoi bezkoryslyvosti [Auction of unprecedented selflessness]. Ukrainskaya tekhnicheskaya gazeta, June 22 (№ 25-26), p. 6 [in Ukrainian].

22. Pervyy Luganskiy [First Lugansk]. (2009). Ukrainskaya tekhnicheskaya gazeta, April 2 (№ 14), p. 3 [in Russian].

23. PAO «Luganskteplovoz» narashchivayet tempy [PJSC «Luganskteplovoz» increases the pace]. (2013). Nasha gazeta, December 17 (№ 186), p. 2 [in Russian].

24. Pro rozrobku i vyrobnytstvo u 1993 - 2000 rokakh mahistralnykh vantazhnykh i pasazhyrskykh elektrovo-ziv: Postanova Kabinetu Ministriv Ukrainy vid 26 chervnia 1993 r. № 480 [On the development and production in 1993 - 2000 of main freight and passenger electric locomotives: Resolution of the Cabinet of Ministers of Ukraine of June 26, 1993 № 480]. Retrieved from https://zakon.rada.gov.ua/laws/show/480-93-\%D0\% BF [in Ukrainian].

25. Pro orhanizatsiiu vyrobnytstva vahoniv dyzel- ta elektropoizdiv: Postanova Kabinetu Ministriv Ukrainy vid 4 chervnia 1994 r. № 364 [On the organization of production of cars of diesel and electric trains: Resolution of the Cabinet of Ministers of Ukraine of June 4, 1994 № 364]. Retrieved from https://zakon.rada.gov.ua/laws/ show/364-94-\%D0\%BF\#Text [in Ukrainian].

26. Rakov, V. A. (1990). Lokomotivy i motorvagonnyy podvizhnoy sostav zheleznykh dorog Sovetskogo Soyuza (1976-1985 gg.) [Locomotives and motorcar rolling stock of the railways of the Soviet Union (19761985)]. Moscow, Transport. 238 p. [in Russian].

27. Rakov, V. A. (1999). Lokomotivy otechestvennykh zheleznykh dorog (1956-1975 gg.) [Locomotives of domestic railways (1956-1975.)]. Moscow, Transport. 443 p. [in Russian].

28. Spektor V. (2009). V kontekste vremeni [In the context of time]. Ukrainskaya tekhnicheskaya gazeta, February 5 (№ 6), p. 10 [in Russian].

29. Amosha, O. I., Aptekar, S. S., Bilopolskyi, M. G., Yurii, S. I. et al. (2011). Strukturni reformy ekonomiky: svitovyi dosvid, in-stytuty, stratehii dlia Ukrainy [Structural reforms of the economy: world experience, institutions, strategies for Ukraine]. Ternopil, Ekonomichna dumka TNEU. 848 p. [in Ukrainian].

30. Tsygankov-Serebryakov, Yu. V. (2006). Lyudi. Gody. Fakty. OAO «KHK» Luganskteplovoz» [People. Years. Data. OJSC «HC» Luganskteplovoz»]. Lugansk. 479 p. [in Russian].

31. Shatovsky, A. S., Volneansky, G. S. (1998). Rozhdennyy trizhdy Kratkiy ocherk istorii Dnepropetrovskogo elektrovozostroitel'nogo zavoda [Born three times. A brief outline of the history of the Dnepropetrovsk electric locomotive plant]. Dnepropetrovsk, RIO APDKT. 263 p. [in Russian].

32. Chumak, V. V., Bratash, V. A. (2002) Perspektivy razvitiya elektrovozostroyeniya $\mathrm{v}$ Ukraine [Prospects for the development of electric locomotive construction in Ukraine]. Transport, Vol. 11, pp. 3-6 [in Russian].

33. Yurova, S. \& Spektor, V. (2011). Sergey Mikheyev: «U nas slavnoye proshloye i khoroshiye perspektivy» [Sergey Mikheev: "We have a glorious past and good prospects”]. Ukrainskaya tekhnicheskaya gazeta, May 31 (№ 20), p. 5 [in Russian]. 
Рубан М. Ю. Розвиток магістрального електровозобудування в Україні (на прикладі диверсифікації виробничої діяльності ДХК «Луганськтеплово3»)

У статті здійснено спробу дослідити економічні передумови становлення магістрального електровозобудування в Україні на прикладі диверсифікації виробничої діяльності Державної холдингової компанії «Луганськтепловоз». Визначено, що наприкінці 1980-х років за відсутності конвертованої валюти для імпорту тягового рухомого складу ВО «Луганськтепловоз» отримало замовлення МШС СРСР на розробку та виробництво вантажопасажирських електровозів власної конструкції. Однак після 1991 р. унаслідок стратегії МШС Російської федерації на підтримку внутрішнього ринку виробників магістральних електровозів, а надто ж лобізму оновленого складу Кабінету Міністрів України щодо спрямування інвестицій на створення державної монопольної корпорації на базі малопотужного НВО «Дніпропетровський електровозобудівний завод», диверсифікація виробничої діяльності ДХК «Луганськтепловоз» зосередилась в менш перспективному напрямі освоєння виробництва моторвагонного рухомого складу соціального призначення. Доводиться теза про те, що з огляду на низьку якість продукції, викликану відсутністю сталого фінансування та грунтовного досвіду розробки магістральної техніки, замовлення електровозів НВК «Електровозобудування» (НВО «ДЕВЗ») було припинено. Натомість локалізація та подальше освоєння промислового виробництва на потужностях ХК «Луганськтепловоз» вантажних електровозів нового покоління, створених на конструкторсько-технологічній основі продукції ТОВ «Новочеркаський електровозобудівний завод», дозволило компанії в стислий термін суттєво підвищити зростання темпів виробництва та розширити напрями співпраці з «Укрзалізницею».

Ключові слова: Луганський тепловозобудівний завод, транспортне машинобудування, магістральне електровозобудування, українські залізниці.

Ruban M. Development of Mainline Electric Locomotive Engineering in Ukraine (on the Example of Diversification of Production Activity of OJSC «Luhanskteplovoz»)

The article attempts to investigate the economic preconditions for the formation of the main electric locomotive industry in Ukraine on the example of diversification of production activities of the State Holding Company «Luhanskteplovoz». It is determined that in the late 1980`s, in the absence of convertible currency for the import of traction rolling stock, Luhanskteplovoz received an order from the USSR Ministry of Railways for the development and production of electric freight and passenger locomotives of its own design. However, after 1991, due to the strategy of the Ministry of Railways of the Russian Federation to support the domestic market of main electric locomotives, and especially the lobbying of the renewed Cabinet of Ministers of Ukraine regarding the direction of investments to create a state monopoly corporation on the basis of low-power SPA «Dnipropetrovsk locomotive plant», diversification of production activities of OJSC
«Luhanskteplovos» focused on a less promising direction of development of production of railcars for social purposes. It is argued that due to the low quality of products caused by the lack of sustainable funding and sound experience in the development of mainline equipment, the order of electric locomotives of SPC «Elektrovozobuduvannia» (SPA«DEVZ») was stopped. Instead, the localization and further development of industrial production at the facilities of HC «Luhanskteplovoz» of new generation freight electric locomotives, created on the basis of design and technological products of LLC «Novocherkassk electric locomotive plant», allowed the company in a short time to significantly increase the growth rate of production and expand cooperation with «Ukrzaliznytsia».

Keywords: Luhansk diesel locomotive plant, transport engineering, mainline electric locomotive engineering, Ukrainian railways.

Рубан Н. Ю. Развитие магистрального электровозостроения в Украине (на примере диверсификации производственной деятельности ГХК «Лугансктепловоз»)

В статье предпринята попытка исследовать экономические предпосылки становления магистрального электровозостроения в Украине на примере диверсификации производственной деятельности Государственной холдинговой компании «Лугансктепловоз». Определено, что в конце 1980-х годов при отсутствии конвертируемой валюты для импорта тягового подвижного состава ПО «Лугансктепловоз» получило заказ МПС СССР на производство грузопассажирских электровозов собственной конструкции. Однако после 1991 г. вследствие стратегии МПС Российской Федерации на поддержку внутреннего рынка производителей магистральных электровозов, а в частности лоббизма обновленного состава Кабинета Министров Украины в направлении инвестиций на создание государственной монопольной компании на базе маломощного НПО «Днепропетровский электровозостроительный завод», диверсификация производственной деятельности ГХК «Лугансктепловоз» сосредоточилась в менее перспективном направлении освоения производства моторвагонного подвижного состава. Доказывается тезис о том, что, учитывая низкое качество продукции, вызванное отсутствием устойчивого финансирования и основательного опыта разработки магистральной техники, заказ электровозов НПК «Электровозостроение» (НПО «ДЭВЗ») был прекращен. В тоже время локализация и дальнейшее освоение промышленного производства на мощностях ХК «Лугансктепловоз» грузовых электровозов нового поколения, созданных на конструкторско-технологической основе продукции ООО «Новочеркасский электровозостроительный завод», позволило компании в сжатые сроки существенно повысить рост темпов производства и расширить направления сотрудничества с «Укрзализныцей».

Ключевые слова: Луганский тепловозостроительный завод, транспортное машиностроение, магистральное электровозостроения, украинские железные дороги.

Received by the editors: 23.11.2020

and final form 29.12.2020 